\title{
The Effects of Government Quality and Economic Indicators on Self-employment in East Africa: Panel Data Analysis
}

\author{
Firdisa Birru Goshu \\ Department of Economics, Wollega University, Nekemte, Dalo 395, Ethiopia
}

\begin{abstract}
Self-employment plays a major role in the economic growth of Africa in general and East African countries in particular. It is a major source of new jobs and a way of employing the entrepreneurial abilities of the population. Moreover, self-employment allows people to do what they want and to follow their passion. However, populations in East Africa face various barriers that hinder their ability to start their own business and/or to become selfemployed. Thus, the aim of this study is to examine the effects of government quality and economic indicators on self-employment. Data was taken for this study from World Bank's World Development Indicators, Worldwide Governance Indicators, African development Bank and United Nations Development Program for eight East African countries for 2010-2018. The countries were selected based on the availability of panel data. The fixed effects result indicated that political Stability, control of corruption indices and Voice and accountability, natural logarithm of electricity access, mobile phone subscriptions, people living below income poverty line and primary education enrolment are favorably affecting self-employment in East Africa. The result also shows that the natural logarithm of employment in industry and real GDP growth have negative coefficients. . These findings suggest that in addition to economic and social indicators government quality have greater effect on self-employment in East Africa.
\end{abstract}

Keywords: Self-employment; fixed effects; Hausman test; Government quality indicators; Panel data; East Africa. DOI: $10.7176 / \mathrm{JESD} / 11-9-05$

Publication date:May $31^{\text {st }} 2020$

\section{Introduction}

Today many African countries are occupied by low-skilled, unemployed youth in urban or rural areas who seek refuge in survival economic activities besides population growth, political instability and violence, corruption. These youth come from poor backgrounds in peri-urban and rural areas and are concentrated in disadvantaged communities and neighborhoods or the slums of large cities (Marleen D. and Saskia H., 2017). Meeting the youth employment challenge in all its dimensions, demographic, economic, and social, and understanding the forces that created the challenge, can open potential pathways toward a better life for young people and better prospects for the countries where they live. Many of these young people are illiterate due to early termination of their schooling resulted from poverty or political instability and violence, internal displacement, or have only completed primary education and also due to deterioration in quality of education they lack the level of education required for formal wage employment or to successfully start their own business ((Marleen D. and Saskia H., 2017; Baah-Boateng 2016). The study by Baah-Boateng (2016) found that in most Sub-Saharan African countries, higher-educated youth are more likely to be unemployed than those with only a basic education.

Participation in self-employment has been increasing from time to time in several developing economies. Various studies conducted in different countries on the challenges of self-employment attest to this fact (Helena M. and Lofstrom M., 2009; liabadi V., 2017; Carlo P, Roberta R, Matteo A., 2004) and most of the world's poor people are self-employed (Gary S., 2019); the percentage of workers who are self-employed increases with age among both men and women (Hipple, 2010) and in Sub-Saharan Africa and South Asia the large majority is selfemployed (Cho, Yoonyoung, Robalino, David, Watson, Samantha, 2016). The share of self-employment among total employment is significant (Maloney, 2004) which was much higher in low- and lower-middle-income countries than in upper-middle-income (28 per cent) and high-income countries (9 per cent) (ILO, 2019) and approximately 74 percent, of the Sub-Saharan Africa's labor force are self-employed (Bhorat H., 2018).

In East Africa, obstacles to self-employment are manifold and rising from day to day. On one hand an increasing number of university graduates and declining quality of education coupled with very limited or no access to paid work is prevailing. The current education system does not create high-quality human capital (Abel T. and Christian F., 2016); a good number of children complete primary school without acquiring basic reading and numeracy skills and lack of required skills and competencies as the main factor contributing to the high rate of youth unemployment (ILO, 2019) and hopes for employment have worsened over time and those who are graduated from higher education stay looking for a job for several years by being unemployed (Yordanos, 2016). On the other hand, political instability, corruption, internal population displacement and lack of finance to start new business are becoming the major challenges to self-employment in East Africa. A considerable proportion of the working-age population is at risk of poverty and many workers find themselves having to take up vulnerable jobs, especially in the informal economy, which are typically associated with low pay and little or no access to 
social protection and rights at work (ILO, 2019).

The studies on the political orientations of small-business owners by scholars often hold that this is a group with rather right-wing political preferences. To mention some, self-employment is associated with free market beliefs, and values such as individualism, autonomy, and self-reliance (Evans and De Graaf, 2013; Gayle et al., 2012; Goss,1991). Youth in East African countries face similar social and economic challenges: high birth rates, poverty, unemployment and underemployment and health problems (ILO, 2019). However, the patterns and severity of these challenges vary by country and sub-country. This study offers a new empirical analysis towards understanding the effect of political stability and corruption on self-employment. A research hypothesis is formulated, by stating a strong positive effect of political stability and corruption on self-employment. In order to prove the claim, empirical data consisting of the control of corruption estimate, political stability and absence of violence estimates were utilized and panel data model was built to assess the impact.

This study is motivated by the following main shortcomings in the literature: the effect of government quality indicator (political stability and control of corruption) and population living below poverty line on selfemployment. Studies on the effects of these covariates on self-employment are very limited and/or scanty in East Africa. Specifically, there is limited understanding of how political stability and absence of violence as well as control of corruption initiates self-employment. Although not well studied, political instability and violence and corruption are rampant and treat to almost all of East African's youth Self-employment. Poor governance, lack of finance, power outages/ limited electricity access, lack of accountability and transparency, low level of institutional control, and extreme poverty and inequality are major obstacles to self-employment in African continent in general and in East Africa in particular.

Generally speaking, self-employment has become a key possible source of new jobs and a way of employing the entrepreneurial abilities of the population in Africa, and it has stimulated many studies and empirical applications. In very broad terms, self-employment can be considered the source of employment in East Africa where poverty and large youth unemployment is prevailing. Despite a flowering literature on the factors underlying the growth of self-employment in Africa, only few studies try to compare and explain self-employment rates across countries.

\section{Literature Review}

According to Investopedia, Self-employment is the state of working for oneself rather than an employer. Selfemployed people generally find their own work rather than being provided with work by an employer, earning income from a profession, a trade or a business that they operate. A self-employed individual does not work for a specific employer who pays them a consistent salary or wage. Self-employment may not be subject to tax withholding and, those self-employed are responsible for paying their taxes. Self-employment can provide a great deal of job flexibility and autonomy; however it also comes with a greater degree of employment risk and more volatile income.

Creation of new business is highly affected by a dishonest or illegal behavior of government officials or corruption and in Africa the wide spread political instability is connected with the high rate of corruption as its politicians, leaders, and public servants illegally collect wealth using public office for private gains (Hammed,2018). Almost in all African countries except for few countries, obstacles to self-employment are various and similar. Previous studies attest to this fact (AFD 2017; Baah-Boateng 2016; Townsend et al., 2017). University graduates are increasing from year to year but, The quality of education in East Africa is Low (Kluve et al. 2016; IMF 2017). African political instability and other related problems is basically challenging the growth of self-employment: civil conflicts, bad governance and poor economic conditions (Antony O., 2008). Moreover, a lack of political will to make youth employment a top priority has created coordination and implementation gaps (Osei Tutu, 2004; Annan, 2008).

Various researches aiming to explore the different determinants of self-employment have been written in the past years (e.g. Lukeš and Zouhar, 2016; Szarucki et al., 2016; AFD 2017; Baah-Boateng 2016; Yordanos, 2016; Townsend et al., 2017; Santos et al., 2017; Bernat et al., 2017; Criaco et al., 2017; Zhang and Acs, 2018; Woronkowicz and Noonan, 2018; Dvouletý et al., 2018; Gary S, 2019; Moyi E., 2019).. The study by Simoes et al. (2016) finds that self-employment is determined by family background, personality characteristics, human capital, health condition, nationality, ethnicity and access to financial resources.

The study by Justice T. (2018) points out that unreliable electricity supply reduces the probability of being self-employed by 35 percent and indicates that lack of electricity access boosts unemployment and has negative impact on employment rates in Africa. Previous studies found inverse relationship between real GDP per capita and self-employment. Countries' development and mature in free enterprise lead to loss of the importance of selfemployment and there is negative relationship between real GDP per capita growth and self-employment rate (Gindling and Newhouse, 2014, Lofstrom M., 2009; liabadi V., 2017; Hipple, 2010; Bhorat H., 2018).

Obviously, many of the most vital difficulties facing working age people in East Africa are not youth-specific and hinder job creation more generally. The research findings by Gindling and Newhouse (2014) showed that only 
7 percent of the self-employed in developing countries are successful. Previous research has predominantly measured self employment using infrastructure, governance and corruption, and access to finance (McKinsey Global Institute 2012; African Development Bank et al., 2012) and only 7 percent of the self-employed in developing countries are successful (Gindling and Newhouse, 2014). Older individuals have more tendencies to enter the self-employment than younger once (Cho Y., Robalino D. and Manuel J., 2015). In the present study, I particularly focus on effects of real GDP per capita growth, population growth, voice and accountability, political stability and absence of violence, control of corruption, people living below income poverty line, education index, mobile cellular subscriptions on self-employment. The connections between self-employment, corruption, political instability and violence are not straightforward. Only limited and contradictory evidence on those connections is available from developing countries (World Bank, 2019).

Furthermore, studies by scholars found that there is strong correlation between mobile cellular subscription and the self-employment rate. For instance, individuals who use mobile phones have $11 \%$ points higher probability of being self-employed relative to those who do not use (Moyi E., 2019). The use of mobile money and mobile commerce enhances the growth prospects of self-employment (Aker, 2010; Amegbe et al., Hanu, C., and Nuwasiima, A. 2017). A study conducted by Gary S (2019) concluded that Self-employment and poverty are closely linked, albeit not perfectly. Employment in industrial sector increases the rate of self-employment by $2 \%$ (Heintz and Pickbourn, 2012) and study, the predicted probability of self-employment is, on average, around 0.03 higher for educated individuals than for the non-educated. Komunte, M. (2015) found that the incidence of selfemployment was higher among educated individuals.

\section{Methodology}

\subsection{Data Source and Description}

The major source of data for this study is the 2010-2018 World Bank's World Development Indicators in East Africa. In addition, data from African Development Bank (AfDB) and UNDP was used. The sample includes eight East African countries (Djibouti, Eritrea, Ethiopia, Kenya, Madagascar, Rwanda, Tanzania and Uganda). The countries were selected based on the availability of panel data. The dependent variable is self-employment rate which is defined as the percentage of total employment estimated by ILO estimate. Based on previous studies and data availability, the researcher used political stability and absence of violence estimate, control of corruption estimate, population growth rate, real GDP growth rate, unemployment rate, Population living below income poverty line, PPP USD 1.90 a day (\%), mobile phone subscriptions (per 100 people) as independent variables.

Data for the independent variables are collected from various sources. Variables such as Real GDP per capita, population growth, employment in industry rate, primary school enrollment and unemployment rate are from the World Development Indicator (WDI database) and Control of corruption index, political stability and absence of violence/terrorism estimate and voice and accountability estimate from Worldwide Governance Indicators (World Bank). Finally, data on mobile phone subscriptions (per 100 people) was taken from African Development Bank database.

\subsection{Empirical Model of self-employment}

To measure the selected determinants' effects on self-employment rate, the researcher used panel data for 8 East African countries for 2010-2018. An important advantage of panel data compared with time series or crosssectional data sets is that they allow identification of certain parameters or questions, without the need to make restrictive assumptions. For example, panel data make it possible to analyze changes on an individual level. As the error term is likely to include country and time-varying effects, a fixed-effects model, is employed. Fixed effects explore the relationship between predictor and outcome variables within an entity (country, person, company, etc.). Each entity has its own individual characteristics that may or may not influence the predictor variables. When using fixed effect the assumption is that something within the individual may impact or bias the predictor or outcome variables and we need to control for this. This is the rationale behind the assumption of the correlation between entity's error term and predictor variables. Fixed effect removes the effect of those timeinvariant characteristics so we can assess the net effect of the predictors on the outcome variable.

The fixed effects model is simply a linear regression model in which the intercept terms vary over the individual units $i$, that is, following Verbeek M. (2017) a fixed effects model is:

$\mathrm{y}_{\mathrm{it}}=\alpha_{\mathrm{i}}+\mathrm{x}_{\mathrm{it}}^{\prime} \beta+\mathrm{u}_{\mathrm{it}}, \mathrm{u}_{\mathrm{it}} \sim \operatorname{IID}\left(0, \delta_{\mathrm{u}}^{2}\right)$

where it is usually assumed that all $\mathrm{x}_{\mathrm{it}}$ are independent of all $\mathrm{u}_{\mathrm{it}}$. We can write this in the usual regression framework by including a dummy variable for each unit $i$ in the model. That is,

$$
y_{i t}=\sum_{j}^{N} \alpha_{j} d_{i j}+x_{i t}^{\prime} \beta+u_{i t}
$$

where $d_{i j}=1$ if $\mathrm{i}=\mathrm{j}$ and 0 elsewhere. We thus have a set of $\mathrm{N}$ dummy variables in the model. The parameters $\alpha_{1}, \ldots, \alpha_{\mathrm{N}}$ and $\beta$ can be estimated by ordinary least squares in. The implied estimator for $\beta$ is referred to as the 
least squares dummy variable (LSDV) estimator.

The OLS estimator for $\beta$, which is called fixed effects estimator, is given by

$$
\widehat{\beta}_{\mathrm{FE}}=\left(\sum_{\mathrm{i}=1}^{\mathrm{N}} \sum_{\mathrm{i}=1}^{\mathrm{T}}\left(\mathrm{x}_{\mathrm{it}}-\overline{\mathrm{x}}_{\mathrm{i}}\right)\left(\mathrm{x}_{\mathrm{it}}-\overline{\mathrm{x}}_{\mathrm{i}}\right)^{\prime}\right)^{-1} \sum_{\mathrm{i}=1}^{\mathrm{N}} \sum_{\mathrm{i}=1}^{\mathrm{T}}\left(\mathrm{x}_{\mathrm{it}}-\overline{\mathrm{x}}_{\mathrm{i}}\right)\left(\mathrm{y}_{\mathrm{it}}-\overline{\mathrm{y}}_{\mathrm{i}}\right)
$$

The rationale behind random effects model is that, unlike the fixed effects model, the variation across entities is assumed to be random and uncorrelated with the predictor or independent variables included in the model:

"...the crucial distinction between fixed and random effects is whether the unobserved individual effect embodies elements that are correlated with the regressors in the model, not whether these effects are stochastic or not" [Green, 2008, p.183].

If we have reason to believe that differences across entities have some influence on our dependent variable then we should use random effects. An advantage of random effects is that we can include time invariant variables. In the fixed effects model these variables are absorbed by the intercept.

The random effects model is:

$\mathrm{Y}_{\mathrm{it}}=\alpha+\beta \mathrm{X}_{\mathrm{it}}+\mu_{\mathrm{i}}+\mathrm{u}_{\mathrm{it}}, \mathrm{u}_{\mathrm{it}} \sim \operatorname{IID}\left(0, \delta_{\mathrm{u}}^{2}\right), \mu_{\mathrm{i}} \sim \operatorname{IID}\left(0, \delta^{2}{ }_{\mu}\right)$

where $\mu_{\mathrm{i}}+\mathrm{u}_{\mathrm{it}}$ is treated as an error term consisting of two components: an individual specific component, which does not vary over time, and a remainder component, which is assumed to be uncorrelated over time. That is, all correlation of the error terms over time is attributed to the individual effects $\mu_{\mathrm{i}}$. It is assumed that $\mu_{\mathrm{i}}$ and $\mathrm{u}_{\mathrm{it}}$ are mutually independent and independent of $\mathrm{x}_{\mathrm{js}}$ (for all $\mathrm{j}$ and $\mathrm{s}$ ). This implies that the OLS estimator for $\alpha$ and $\beta$ is unbiased and consistent.

In general, random effects assume that the entity's error term is not correlated with the predictors which allows for time-invariant variables to play a role as explanatory variables. In random-effects we need to specify those individual characteristics that may or may not influence the predictor variables. The problem with this is that some variables may not be available therefore leading to omitted variable bias in the model. Random effect allows to generalize the inferences beyond the sample used in the model. Conceptual model of self-employment is given below:

\section{Government Quality Indicators: \\ $\checkmark$ Voice and Accountability, Estimate \\ $\checkmark$ Political Stability and Absence of Violence \\ $\checkmark$ Control of Corruption, Estimate}

\begin{tabular}{ll}
\multicolumn{2}{c}{ Demographic and Economic indicators } \\
$\checkmark$ & Population growth rate \\
$\checkmark$ & Real GDP growth rate \\
$\checkmark$ & employment in Industry \\
$\checkmark$ & Unemployment, (\% of total labor force) \\
$\checkmark$ & Primary School enrollment \\
$\checkmark$ & Mobile phone subscriptions (per 100 people) \\
$\checkmark$ & Population living below income poverty line
\end{tabular}

Figure1: Conceptual Framework: developed from literature and own experience (2020) 


\section{DISCUSSION}

\subsection{Descriptive Statistics}

Table 1: Summary of Variables used in the empirical model

\begin{tabular}{|l|l|c|c|c|c|}
\hline Variable & \multicolumn{1}{|c|}{ Description } & Mean & Std.Dev. & Min & Max \\
\hline Inselfemp & $\begin{array}{l}\text { Natural logarithm of Self-employed, (\% of total } \\
\text { employment) }\end{array}$ & 4.305 & .223 & 3.859 & 4.507 \\
\hline vae & Voice and Accountability, Estimate & -.96 & .651 & -2.226 & -.115 \\
\hline pve & $\begin{array}{l}\text { Political Stability and Absence of Violence/Terrorism, } \\
\text { Estimate }\end{array}$ & -.69 & .506 & -1.68 & .253 \\
\hline cce & Control of Corruption, Estimate & -.61 & .509 & -1.316 & .762 \\
\hline lnelaccess & Natural logarithm of electricity access & 3.344 & .496 & 2.272 & 4.163 \\
\hline lnempind & Natural log of employment in Industry & 2.076 & .214 & 1.743 & 2.555 \\
\hline lnempagri & Natural log of in agriculture & 4.127 & .209 & 3.524 & 4.375 \\
\hline mselfem & Self-employed, (\% of male employment) & 70.359 & 16.684 & 42.029 & 88.183 \\
\hline fselfemp & Self-employed, (\% of female employment) & 81.81 & 13.157 & 55.566 & 93.625 \\
\hline lnmobsub & $\begin{array}{l}\text { Natural log of Mobile phone subscriptions (per 100 } \\
\text { people) }\end{array}$ & 3.674 & .639 & 1.765 & 4.568 \\
\hline bpovline & $\begin{array}{l}\text { Population living below income poverty line, PPP USD } \\
1.90 \text { a day (\%) }\end{array}$ & .493 & .041 & .412 & .579 \\
\hline RGDPgrw & Real GDP per capita growth & 6.042 & 6.137 & - & 30.934 \\
\hline lnpopgrwth & Natural log of population growth rate & .901 & .307 & .01 & 1.322 \\
\hline penroll & Natural log of primary School Enrollment & .409 & .089 & .269 & .526 \\
\hline
\end{tabular}

Source: Computed from WBES data (2010-2018)

\subsection{Self-employment and Unemployment in East Africa}

In East Africa the growing working-age population coupled with inflation and political instability is posing strong labour market challenges in the coming years. The majority of population in the sub-region is living in extreme poverty and some in moderate poverty and the percentage of population living in extreme poverty is projected to rise, since poverty reduction in the sub-region is going on at a slower pace than elsewhere. In East Africa selfemployment is not evenly distributed. Djibouti has the lowest self-employment rate from the eight East African countries. As Figure 2 below indicates, mean self-employment rate of Djibouti was 48.5557 for 2010-2018, which is the lowest compared to the mean self-employment rates of other East African countries under study. On contrary the largest rate of self-employment was in Madagascar with 89.4292 followed by Ethiopia, Eritrea and Tanzania in that order.

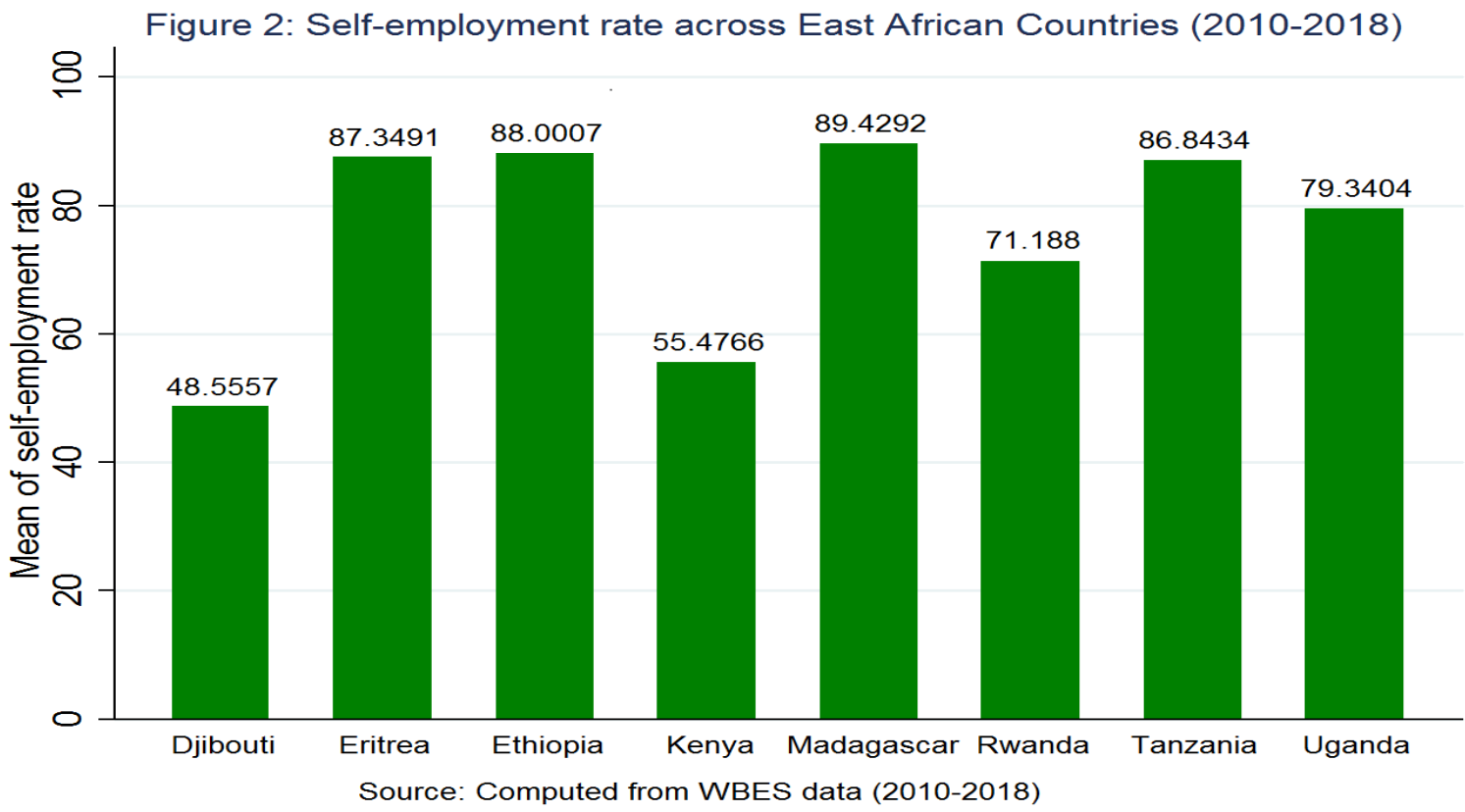

Self-employment creation has kept pace with population growth but joblessness remains high. With too few 
formal jobs to absorb East Africa's rapidly increasing labor force and fast urbanization, the share of the active labor force in self-employment is rising faster than in agricultural. Self-employment in the industrial sector has grown fastest, but agriculture is still the largest employer. In many of East African countries the number employed in industry more than doubled, while the number employed in agriculture less than doubled. However, the share of self-employment in agriculture is more than that in industry. Today almost in all East African countries unemployment rate is higher in cities than in rural. Generally, in East Africa the majority of individuals from lowincome households are confined to low quality jobs and rate of unemployment is awfully similar crosswise households. Similarly in the sub-region, individuals from low-income households are inconsistently engaged in self-employment and informal wage work, and in agriculture and low value-added sectors and have nearly no access to better paid wage employments.

This paper focuses on 8 East African countries, the region with the lowest per capita incomes, largest shares of the work force employed in agriculture and lowest agricultural labor productivity. Over this period, the average self-employment rate was declining from $78.10 \%$ in 2010 to $74.33 \%$ in 2018 across East African countries. According to World Bank data, employment as percentage of total employment is higher in agriculture in East African countries which is near $80 \%$ while percentage of total employment in industrial sector is less than $20 \%$. Figure 3 below reports the percentage of self-employed in agriculture, in industry and the overall self-employment rate in East African countries between 2010 and 2018.

Figure 3: Self-employment across main sectors in East Africa (2010-2018)

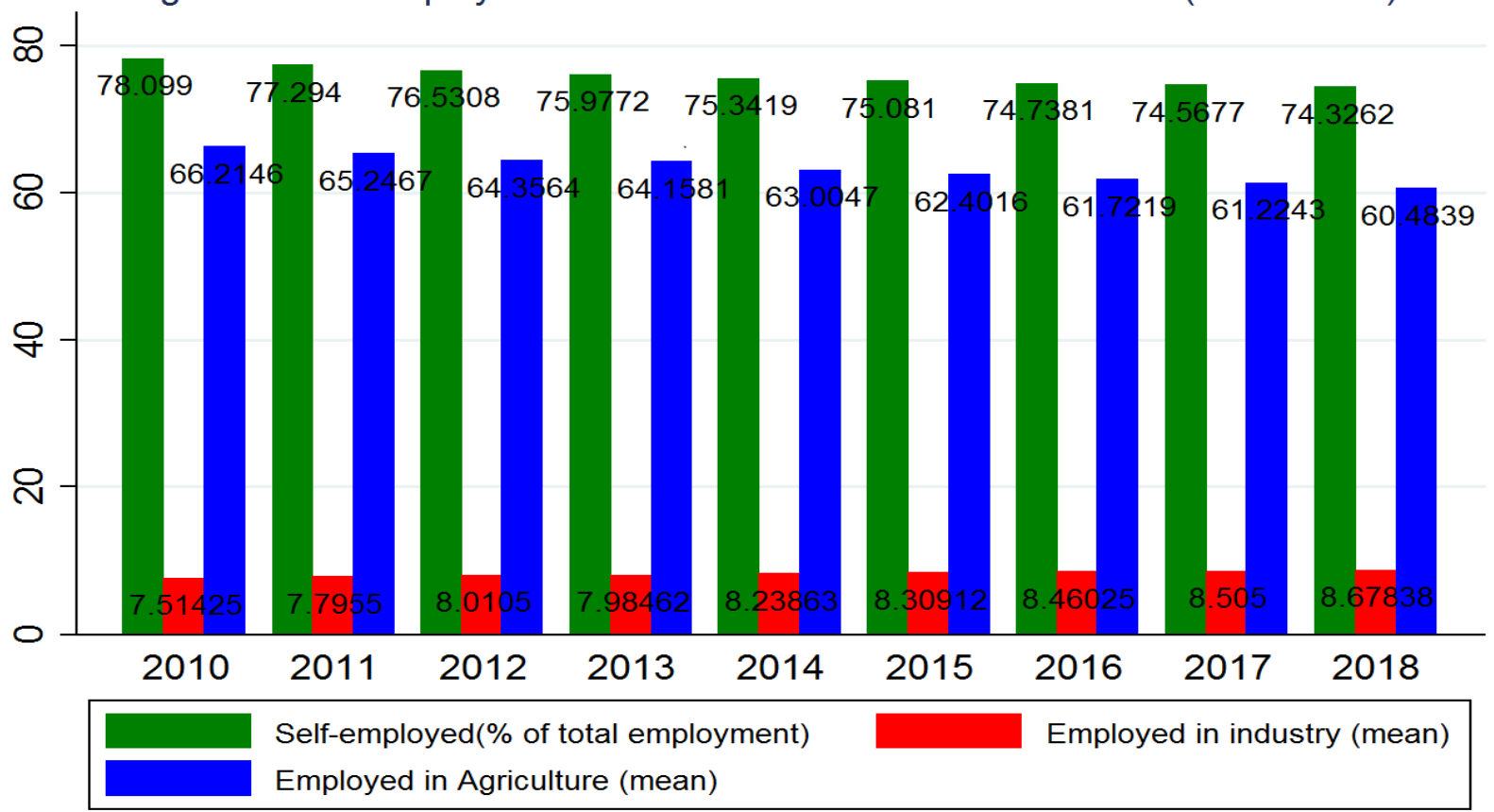

Source: Computed from WBES data (2010-2018)

The East African countries are plagued by violence, corruption, unemployment and extreme poverty.

The figure below shows how African countries compare with one another, taking into account unemployment rate as an indicator. Djibouti is with the highest unemployment rate (worst) while countries with the lowest unemployment rate include Rwanda, Uganda and Madagascar. In Djibouti, the unemployment rate measures the number of people actively looking for a job as a percentage of the labour force. Djibouti is mostly barren, with little development in the agricultural and industrial sectors. The country has a harsh climate, a largely unskilled labour force, and limited natural resources. As such, Djibouti's economy is commanded by the services sector, providing services as both a transit port for the region and as an international transshipment and refueling centre. Countries with almost stable rate of unemployment are Djibouti, Eritrea, Kenya and Ethiopia. Greater fluctuation in the rate of unemployment is found in Madagascar, Uganda and Tanzania. 


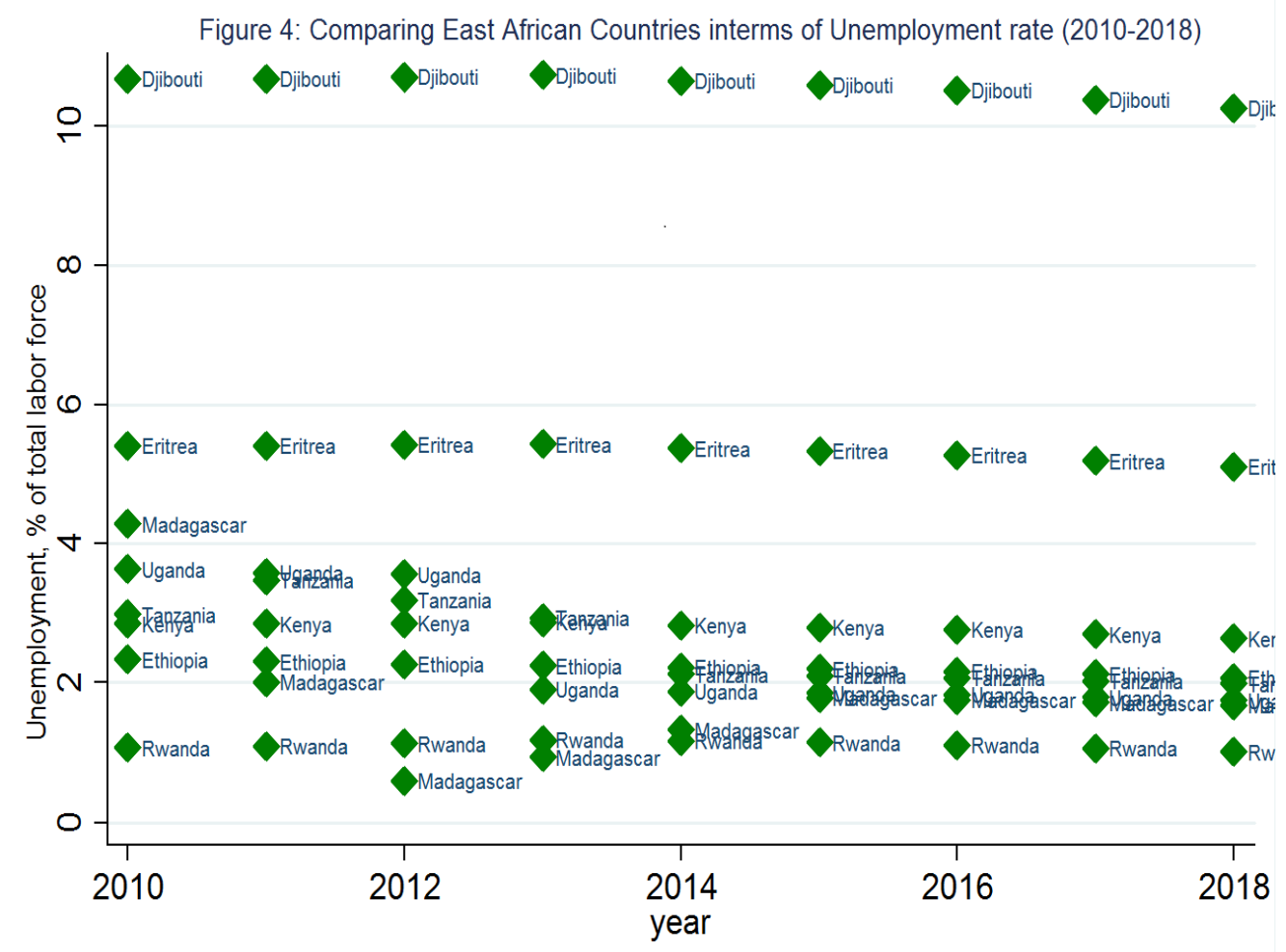

Source: WBES data (2010-2018)

\subsection{Mobile phone subscriptions and its trends in East Africa}

According to appsafrica (2020), as mobile phone access improves in Africa, its mobile economy is expected to reach new heights and half the population in Sub-Saharan Africa will subscribe to mobile phone services by 2025 . East Africa's mobile subscription is experiencing rapid growth per 100 people. According to figure 5 below the mean population's mobile subscription has been increasing from 31.4333 in 2010 to 58.4464 in 2018 on average. Increasing mobile subscriptions is an indication of increasing access to information on new business creation and self-employment.

As east Africa's mobile subscription becomes stronger, so will self-employment rate. As figure 6 report estimates, Eritrea displayed the lowest overall average of mobile subscription, with around 13.1339 per 100 people. Across all eight countries (Djibouti, Eritrea, Ethiopia, Kenya, Madagascar, Rwanda, Tanzania, and Uganda), Kenya showed the highest mean mobile subscription, with about 75.0565 per 100 people followed by Tanzania and Rwanda with 64.9564 and 63.3579, respectively.

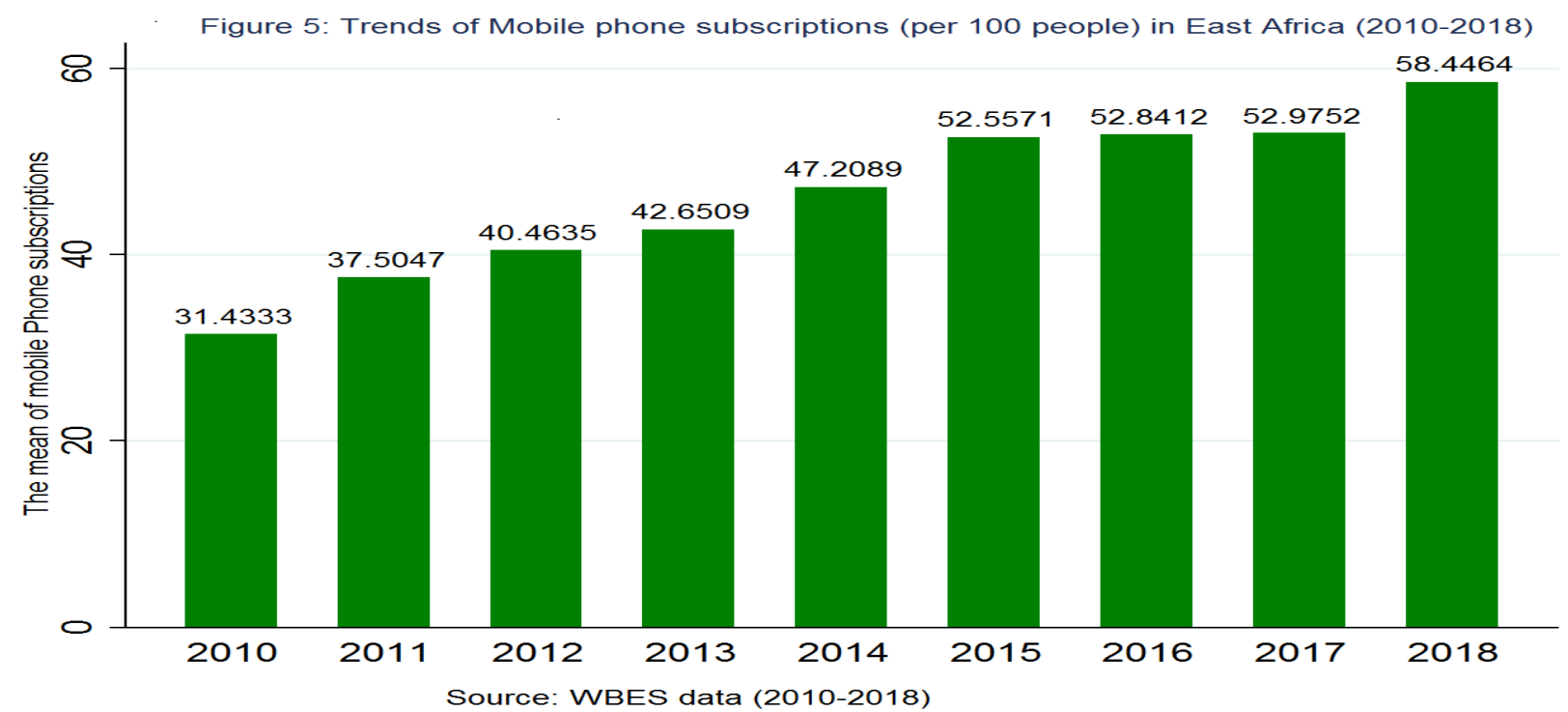


Figure 6: Mobile Phone subscription per 100 population across countries (2010-2018)

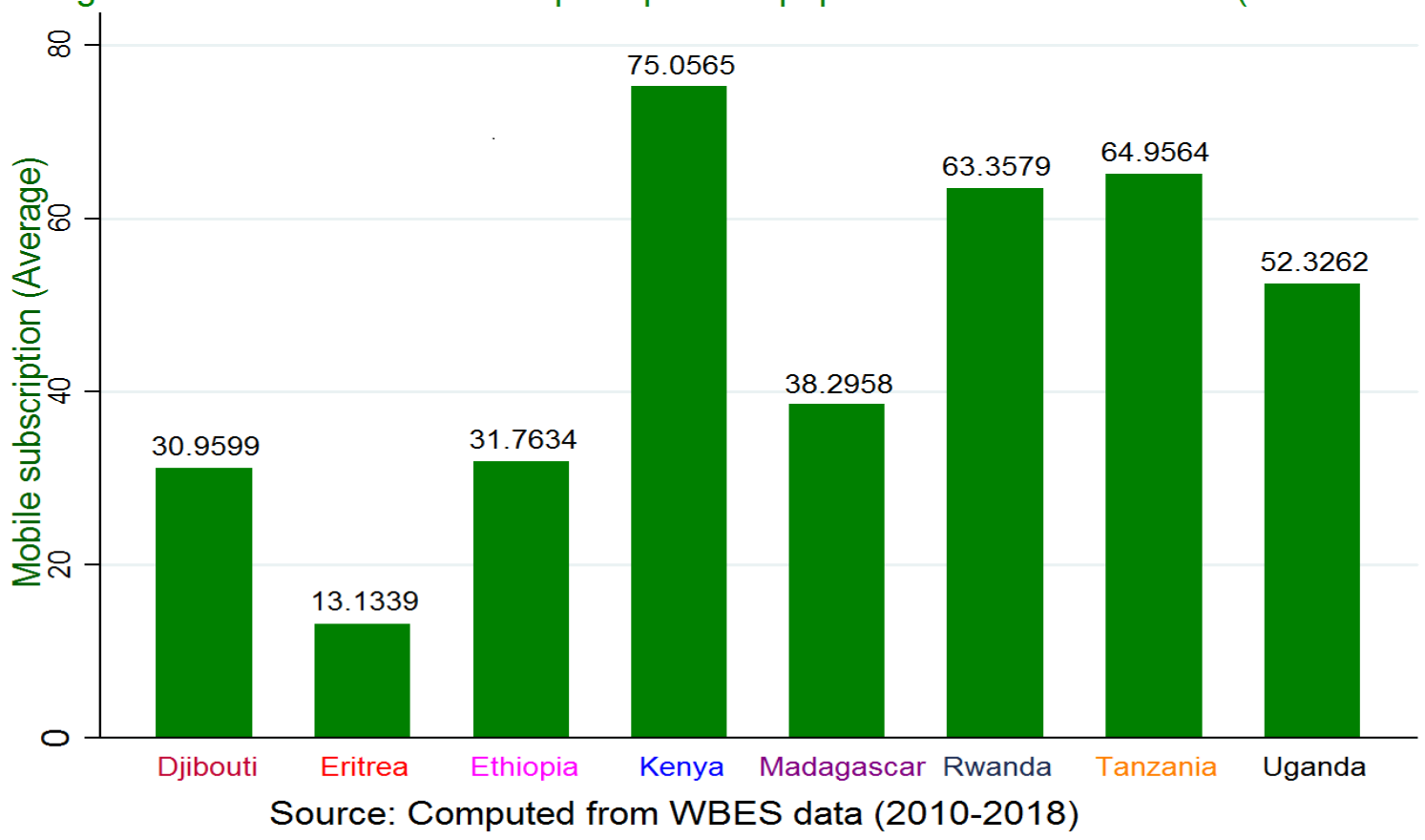

\subsection{The gender gap in self-employment in East Africa}

Gender disparities in self-employment in East Africa are also evident. There is a great gender gap in selfemployment and job creation. Women greatly outnumber men among the self-employed; they are less likely than men to have paid employees. The gender composition of self-employed people contrasts sharply with the makeup of employment overall. From 2010 to 2018, east Africa's females' self-employment exceeds men's for all of the eight East African countries under discussion. Eritrea has the largest percentage of females self-employed with 93.3429\% followed by Madagascar and Tanzania with $92.1191 \%$ and $90.9318 \%$, respectively. Djibouti's females' self-employment is the lowest $(56.9279 \%)$ followed by Kenya $(64.3939 \%)$. Interms of men self-employment, Madagascar has the largest percentage (86.841\%) followed by Ethiopia $(85.7638 \%)$, Tanzania $(83.0483 \%)$ and Eritrea $(82.1614 \%)$, respectively.

Figure 7 report indicates the percentage of self-employed is higher for females than males in East Africa.

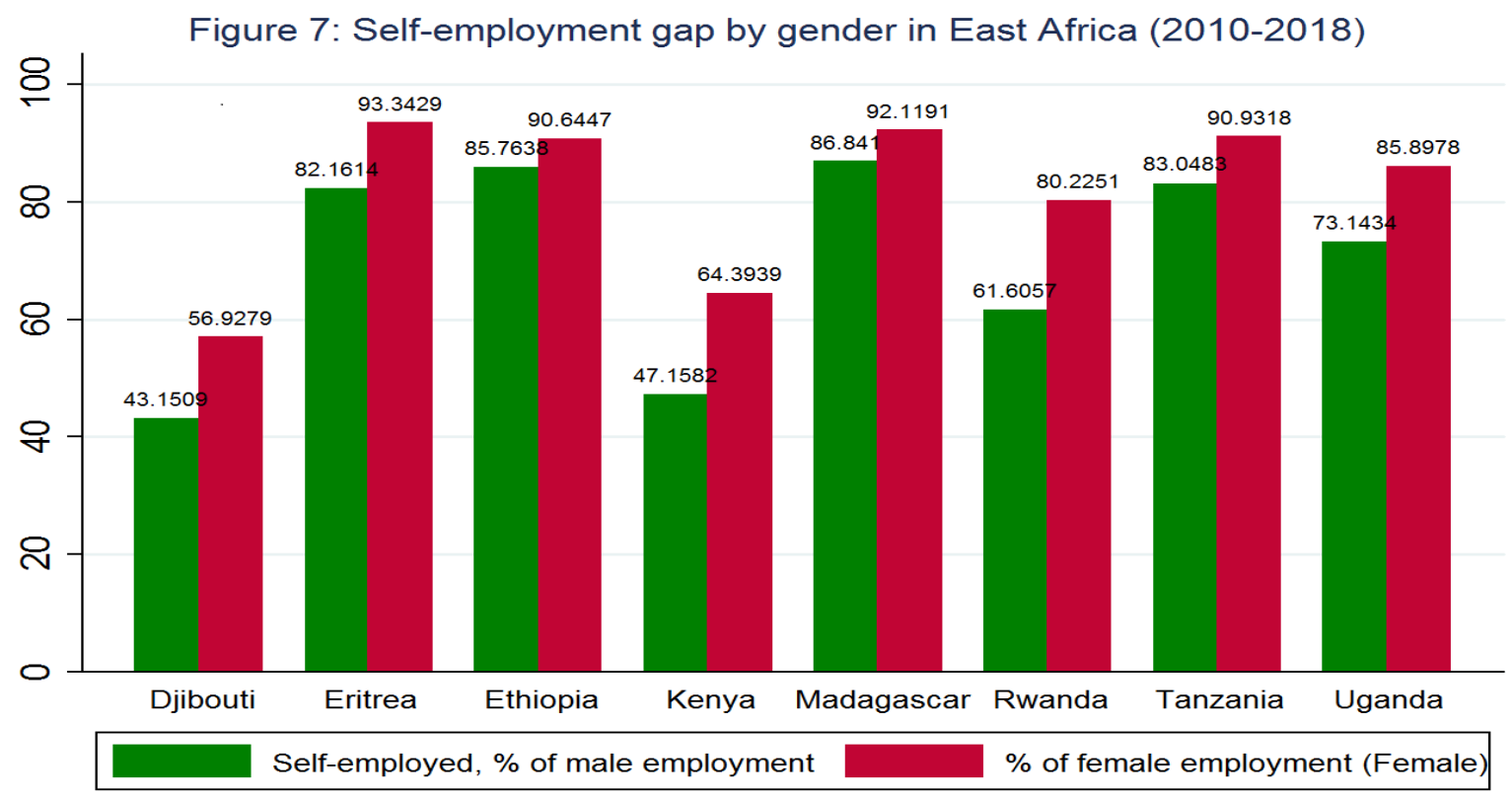

Source: Computed from WBES data (2010-2018) 


\subsection{Fixed Effects or Random Effects Model}

To decide between fixed or random effects we can run a Hausman test where the null hypothesis is that the preferred model is random effects vs the alternative the fixed effects (Green, 2008). It basically tests whether the unique errors $\left(\mathrm{u}_{\mathrm{i}}\right)$ are correlated with the regressors; the null hypothesis is they are not.

Table 2: Hausman Specification test

\begin{tabular}{|c|c|c|c|c|}
\hline \multirow[b]{2}{*}{ Variable } & \multicolumn{2}{|c|}{---- Coefficients ---- } & \multirow[b]{2}{*}{$\begin{array}{c}(\mathrm{b}-\mathrm{B}) \\
\text { Difference }\end{array}$} & \multirow[b]{2}{*}{$\begin{array}{c}\operatorname{Sqrt}(\operatorname{diag}(\mathrm{V}-\mathrm{b}-\mathrm{V}-\mathrm{B})) \\
\text { S.E. }\end{array}$} \\
\hline & $\begin{array}{c}\text { (b) } \\
\text { fixed }\end{array}$ & $\begin{array}{c}\text { (B) } \\
\text { random }\end{array}$ & & \\
\hline vae & 0.0022 & 0.0083 & -0.0061 & 0.0033 \\
\hline pve & 0.0020 & -0.0019 & 0.0039 & 0.0012 \\
\hline cce & 0.0034 & -0.0010 & 0.0044 & 0.0019 \\
\hline lnelaccess & 0.0016 & -0.0012 & 0.0028 & 0.0012 \\
\hline lnempind & 0.0293 & 0.0397 & -0.0104 & 0.0070 \\
\hline lnmobsub & 0.0130 & 0.0610 & -0.0480 & 0.0010 \\
\hline bpovline & 0.1680 & 0.0130 & 0.1550 & 0.0435 \\
\hline RGDPgrowth & -0.0632 & -0.049 & -0.0142 & 0.0011 \\
\hline Lnpopgrwth & 0.1300 & 0.0161 & 0.1139 & 0.0110 \\
\hline lnpenroll & 0.1200 & 0.0250 & 0.0950 & 0.0632 \\
\hline $\begin{array}{r}\operatorname{chi} 2(7)= \\
= \\
\text { Prob }>\text { chi2 }=\end{array}$ & $\begin{array}{l}\text { B)' }\left[\left(V_{-} b-V\right.\right. \\
46.78 \\
0.0000\end{array}$ & 1)](b-B) & & \\
\hline
\end{tabular}

Note: we therefore conclude for fixed effects at any level of significance.

From this result as Prob $>\mathrm{chi}^{2}=0.0000$ is far less than 0.05. Therefore, fixed effect model is appropriate. Under the current specification, the initial hypothesis that the individual-level effects are adequately modeled by a random-effects model is deeply rejected.

The LM test helps decide between a random effects regression and a simple OLS regression. The null hypothesis in the LM test is that variances across entities are zero. This is, no significant difference across units (i.e. no panel effect).

Table 3: Summary of Breusch-Pagan test for random effects:

\begin{tabular}{|c|c|c|}
\hline \multicolumn{3}{|c|}{$\operatorname{lnselfemp}[$ Country,t] $=\mathrm{Xb}+\mathrm{u}[$ Country] $+\mathrm{e}[$ Country,t] } \\
\hline Estimated Results: & Var & $\mathrm{sd}=\mathrm{sqrt}($ Var $)$ \\
\hline $\ln$ selfemp & .0497632 & .2230768 \\
\hline $\mathrm{e}$ & $9.75 \mathrm{e}-07$ & .0009875 \\
\hline $\mathrm{u}$ & 0.0117891 & 0.0217884 \\
\hline Test: & Var(u) $=0 ; \quad$ chi2 $(01)=0.000 ;$ Prob $>$ chi2 $=0.3400$ \\
\hline \multicolumn{2}{|c|}{ Source: Computed based on WBES data $(2010-2018)$} \\
\hline
\end{tabular}

Note: We therefore conclude for fixed effects at any level of significance

Here the null hypothesis is accepted and conclude that random effects is not appropriate, because Prob $>$ chi2 $=0.3400$ exceeds 0.05 . This is, no evidence of significant differences across countries, therefore you can run a simple OLS regression.

The fixed effect results show how changes in self-employment status are related to changes in government quality indicators and other covariates by controlling for unobserved, time-invariant individual characteristics. Results of the fixed effects are reported in Table 3 below. The results of the fixed effects panel analysis show that government quality indicators (political Stability and absence violence, control of corruption indices and Voice and accountability) have a positive and significant effect on East African's self-employment rate with coefficients $0.0743,0.1339$ and 0.1811 , having p-values $0.000,0.002$ and 0.016 , respectively. Similarly, the result of the natural logarithm of electricity access has a positive relationship with natural logarithm of self-employment rate, having coefficient 0.0158 with p-value 0.099 . This shows that with more electricity access rate of self-employment will obviously be high.

The estimation result also indicates that natural logarithm of mobile phone subscriptions, \% of people living below income poverty line and natural $\log$ of population growth have a positive and significant effect on East African's self-employment rate with coefficients $0.0129,0.1676$ and 0.1280 , having p-values $0.065,0.000$ and 0.085 , respectively. Similarly, the result of the natural logarithm of employment in industry and real GDP growth rate have negative relationship with natural logarithm of self-employment rate, having coefficients -0.0293 and 0.0632 with p-values 0.000 and 0.006 , respectively. As the percentage of people living below income poverty line increase, self-employment rate increases. This finding supports the research finding by Gary S., (2019). The positive correlation between mobile phone subscription and self-employment is similar with the findings of Moyi E., (2019), Aker, (2010), Amegbe et al., Hanu, C., and Nuwasiima A., (2017). 
The empirical evidence on the association between self-employment and education is very mixed in the literature, and so are the results of my estimation. I test the relationship between primary education enrolment and the self-employment rate: there is positive and statistically significant relationship at 1 percent level with coefficient 0.0195 . The positive relation between primary enrolment and self-employment rate supports the hypothesis that some basic skills are required in order to start a business and become self-employed. The result obtained shares similarities with the findings of Carlo P., Roberta R. and Matteo A., (2004) on effect of primary education enrolment on self-employment rate. Carlo P., Roberta R. and Matteo A., (2004) tested the relationship between primary education and the self-employment rate and concluded that there is positive and statistically significant relationship between primary education enrollment and the self-employment rate at 10 percent level. The positive relation between primary enrolment and self-employment rate supports the hypothesis that some basic skills are required in order to start a business.

Table 3: The determinants of self-employment in developing countries (Fixed Effects estimation result)

Number of obs $=72 ; \mathrm{F}(10,51)=3963.01 ;$ Prob $>\mathrm{F}=0.000$

\begin{tabular}{|c|c|c|c|c|}
\hline Natural log of self-employment & Coef. & Std. Err. & $\mathrm{t}$ & $\mathrm{P}>|\mathrm{t}|$ \\
\hline Political Stability and absence of violence & $0.0743 * * *$ & 0.0074 & 10.04 & 0.000 \\
\hline Control of corruption estimate & $0.1339 * * *$ & 0.0103 & 2.22 & 0.002 \\
\hline Voice and accountability estimate & $0.1811^{* *}$ & 0.0730 & 2.48 & 0.016 \\
\hline Natural log of electricity access & $0.0158 *$ & 0.0040 & 3.95 & 0.099 \\
\hline Natural log of employment in industry & $-0.0293 * * *$ & -0.0038 & 7.71 & 0.000 \\
\hline Natural log of primary School Enrollment & $0.0195 * * *$ & 0.0031 & 6.29 & 0.000 \\
\hline Natural log of Mobile phone subscriptions & $0.0129 *$ & 0.0068 & 1.9 & 0.065 \\
\hline$\%$ of people living below income poverty line & $0.1676 * * *$ & 0.0289 & 5.8 & 0.000 \\
\hline Real GDP growth $(\%)$ & $-0.0632 * * *$ & 0.0022 & -28.73 & 0.006 \\
\hline Natural log of population growth & $0.1280 *$ & 0.0732 & 1.75 & 0.085 \\
\hline sigma_u & \multicolumn{4}{|l|}{0.291757} \\
\hline sigma_e & \multicolumn{4}{|c|}{0.480987} \\
\hline rho & \multicolumn{4}{|c|}{0.268973 (fraction of variance due to $\mathrm{u}$ i) } \\
\hline $\mathrm{F}$ test that all $\mathrm{u} \_\mathrm{i}=0: \mathrm{F}(7,51)=30.36$ & \multicolumn{4}{|c|}{ Prob $>F=0.0000$} \\
\hline
\end{tabular}

Source: Computed based on WBES data (2010-2018)

\section{CONCLUSIONS}

The objective of this paper was to establish a number of key facts about the relationship between government quality and self-employment, and economic indicators and self-employment in east Africa. In the $21^{\text {st }}$ century, self-employment has begun to be stared as a vital potential source of new jobs and a way of employing the entrepreneurial abilities of the population, and it has urged various studies and empirical uses. In awfully extensive terms, self-employment can be regarded as the residual category of useful employment not remunerated by a wage or salary (ILO, various issues). However, few studies are available on determinants of self-employment in East African countries, where the phenomenon is incredibly important, and it is fundamentally related to the informal economy.

The present study analyses the determinants of self-employment in East African countries, in order to identify the existence of cross-national differences and to find effect of government quality indicators, mobile phone subscriptions, population growth, real GDP growth and electricity access on self-employment. This may help to provide some indications on the effect of good governance on self-employment in the East Africa, which has not been attempted, as far as I am aware, in the existing literature.

The main results of the present analysis may be summarized as follows.

The study indicated that the government quality indicators (political Stability and absence violence, control of corruption indices and Voice and accountability) are favorably affecting self-employment in East Africa. The governments and political parties should look into this matter and tirelessly work on stabilizing the region that self-employment should not be compromised specially for youth. The study also indicated that natural logarithm of electricity access has a positive relationship with natural logarithm of self-employment rate. Thus, governments and other concerned bodies should support the expansion of grid-connections and electricity access for the population in general and for those in need of job creation. Furthermore, the governments should encourage mobile phone subscriptions and find the way out for those living below income poverty line as the coefficients of these variables are positive and statistically significant. Similarly, the fixed effects result also shows that the natural logarithm of employment in industry and real GDP growth both have negative coefficients. With the expansion of industries and industrial parks the percentage of wage employment increases but self-employment decreases.

Finally, the coefficient on primary education enrolment is positive and statistically significant at 1 percent 
level because, basic skills are required in order to start a business and become self-employed. The research findings of Carlo P., Roberta R. and Matteo A., (2004) attest to this fact. Therefore, the importance of governments in enhancing basic education is highly recommended and thereby play a more active and effective role in supporting development, self-employment may spark a positive upright circle with higher tax collection, higher government support, and in turn higher self-employment.

In Africa in general and East Africa in particular, self-employment remains a major concern and concerted efforts must be made to keep up with growth rates. The flagship African Economic Outlook Report pinpoints industrialization as a key to the region's employment mystery. According to the African Development Bank (2018), East Africa's economy races ahead of its African peers and is leading the continent with GDP growth estimated at 5.7 percent in 2018 , followed by North Africa at 4.9 percent, West Africa at 3.3 percent, Central Africa at 2.2 percent, and Southern Africa at 1.2 percent. Economic growth across Eastern Africa will remain at a robust 5.9 percent in 2019, making it a promising investment and manufacturing destination. Within the region, Ethiopia is in the lead as the fastest growing economy with a predicted $8.2 \%$ growth in 2019 , while Rwanda (7.8\%); Tanzania (6.6\%); Kenya (6\%), Djibouti(5.9\%), Uganda(5.3\%), Madagascar (5.1\%) and Eritrea (3.7\%) follow behind.

\section{ACKNOWLEDGEMENTS}

First and foremost my sincere gratitude and thanks to the Almighty God, who supplied the strength and capability to accomplish this work. I forward my special thanks to my wife Kiya Emiru Galata for her continuous moral support during this work. I also appreciate the comments received from my friends Mr. Melkamu Wolde and Mr. Desalegn Eticha at Department of Economics of Wollega University. All the remaining errors are mine.

\section{References}

Abel T. and Christian F., 2016. Challenges and Prospects of Entrepreneurship Development and Job Creation for Youth Unemployed: Evidence from Addis Ababa and Dire Dawa city Administrations, Ethiopia. Community Based Monitoring System-Ethiopia (CBMS -12658). Research Paper 1 - Youth Employment and Entrepreneurship (YEE).

African Development Bank., 2016. 'Jobs for Youth in Africa Strategy for Creating 25 Million Jobs and Equipping 50 Million Youth 2016-2025’, AFDB document.

Aker, J. C., 2010. Mobile phones and economic development in Africa. Journal of Economic Perspectives, 24(3), 207-232.

Allen et al., 2016. 'Agrifood Youth Employment and engagement Study (AGYEES)', Available at: https://drive.google.com/drive/folders/0B8WgAQsIvClPT1pRYUh2dHJtbUE.

Amegbe, H., Hanu, C., \& Nuwasiima, A., 2017. Small-scale individual entrepreneurs (SIEs) and the usage of mobile money (Mmoney) and mobile commerce (M-commerce) in facilitating business growth in Ghana. Management Science Letters, 7(8), 373-384.

Antony O., 2008. Political instability in Africa Where the problem lies and alternative perspectives: The African Diaspora Policy Centre, Amsterdam.

Baah-Boateng, W., 2016. 'The youth unemployment challenge in Africa: What are the drivers?', The Economic and Labour Relations Review, vol. 27, no. 4, 413-431.

Carlo P, Roberta R, Matteo A., 2004. An Empirical Study Of The Determinants Of Self-Employment In Developing Countries, John Wiley \& Sons, Ltd.

Getinet H., 2008. Determinants of Self-Employment in Urban Ethiopia: Panel data based evidence. PSI report No 908 .

Hammed, A.A., 2018. Corruption, political instability and development Nexus in Africa: A call for sequential policies reforms.(Munich personal RePEc archive) MPRA paper no. 8527.https://mpra.ub.unimuenchen.de/85277/.

Heintz, J., \& Pickbourn, L., 2012. The determinants of selection into non-agricultural self-employment in Ghana. Margin: The Journal of Applied Economic Research, 6(2), 181-209.

Hipple, S. F., 2010. Self-employment in the United States. Monthly Labor Review. Retrieved from http://www.bls.gov/opub/mlr/2010/ 09/art2full.pdf.

Komunte, M., 2015. Usage of mobile technology in women entrepreneurs: A case study of Uganda. The African Journal of Information Systems, 7(3), 3.

Maloney, W., 2004. Informality revisited. World Development, 3(7), 1159-1178.

Marleen D. and Saskia H., 2017. Boosting youth employment in Africa: what works and why?

Moyi, E. D., 2019.The effect of mobile technology on self-employment in Kenya.

Townsend, R. et al., 2017. 'FUTURE of FOOD: Shaping the Food System to Deliver Jobs', Available at: https://openknowledge.worldbank.org/handle/10986/26506.

World Bank., 2019. Youth employment in Sub-Saharan Africa. (Washington, DC). Justice T. (2018). Jobs! Electricity Shortages and Unemployment in Africa. 